\title{
THE MUNDUS ATTINIS IN THE LUCANIAN CONSILINUM (CAMPANIA) AS A METAPHOR OF DEATH AND RE-BIRTH
}

\begin{abstract}
Summary: This chapter aims to reconsider an inscription from Consilinum (3rd century CE), in which we find the problematic mention of a mundus Attinis. This inscription has been almost neglected by scholars: it has been analyzed in a systematic way only in an article in Latin language back in 1978. It is not easy to explain what mundus exactly represented to the ancient Romans, but we can assert for sure that it was a holy place in connection with the worship of the gods of the underworld. The connection between Cybele, Attis, and the underworld is well known, but this is the only mention we have of a mundus Attinis i.e. Attidis. It might be connected to the (mystic?) rites in honor of the dead Attis, symbolized by a pine, who, during the Hilaria, was carried in an underground chamber for lamentations, before his new life. In my opinion, we might also think of the mundus as a sort of reversed womb, related to the figure of the Magna Mater, in which birth and death come together and overlap.
\end{abstract}

Key words: Attis, Cybele, mundus, Neoplatonism, Magna Graecia, Etruria

\section{INTRODUCTION}

The main object of this paper is an inscription from the Lucanian town Consilinum, in Campania (3rd century CE), in which we may find the problematic mention of a mundus Attinis. Indeed, this inscription has been quite neglected by scholars: It has been analysed in a systematic way only in an article written in Latin back in 1978: Victorius Bracco: Sanctus Mundus Attinis in finibus Cosilinatium (in Hommage à M. $J$. Vermaseren I. Leiden 1978, 346-377).

Here is the inscription; there are two possible readings:

1) Sanctum / mundum / Attinis p(ro) r(editu) / a fundament(is) / Helviae Abascante / et Capitolina f(ilia) / d(ecreto) d(ecurionum) p(ecunia) s(ua) f(ecerunt) 
2) Sanctum / mundum / Attinis p(opuli) R(omani) / a fundament(is) / Helviae Abascante / et Capitolina f(ilia) / d(ecreto) d(ecurionum) p(ecunia) s(ua) f(ecerunt $)^{1}$

As we will see, we will follow the first one.

As in a newspaper report, I think it is necessary to answer the five Ws, in order to come to some conclusions: what, who, why, but, above all, where and when.

\section{WHAT IS A MUNDUS?}

First of all, we have to establish the main "physical" object of our research, therefore what a mundus is. This is not an easy task, since the ancient Romans themselves seem to be quite confused in this regard. In fact, the Latin word mundus can indicate both a specific sacred place usually connected with the foundation of the city (the most famous one is that in Rome, but we can also mention the mundi in Satricum, Cosa, Tarquinia, Cerveteri, ${ }^{2}$ Capua, ${ }^{3}$ Corfinium, ${ }^{4}$ possibly Grumentum $)^{5}$ and altars and other buildings sacred to the underworld gods.

There are basically two different kind of sources which can help us to understand the meanings of the mundus: those who put the mundus in connection to the foundation of Rome by Romulus (e.g. Ov. Fasti 4. 819-825 and Plu. Rom. 11); and those who describe the mundus as a place sacred to Ceres and the underworld gods, which was opened three times a year (e.g. Festus, p. 144 L.). However, as Coarelli ${ }^{6}$ has pointed out in the Seventies, there is no real contradiction between the two versions: in Rome, there was only one mundus related to both the foundation and the chthonian and agrarian deities. This mundus has to be identified with the so-called umbilicus Romae in the Western part of the Forum, adjacent the Comitium. The mun$d u s$ and the Comitium are two symbolic monuments placed at the heart of the City, in

${ }^{1}$ Bracco, V.: Sanctus Mundus Attinis in finibus Cosilinatium. In DE BOER, M. B. - EdRIDGE, T. A. (eds): Hommages à M. J. Vermaseren. Vol. I. Leiden 1978, 346-377; DeVIJVER, H. - VAN WonTERGHEM, F.: Un "mundus" (Cereris?) a Corfinium: Nuova lettura e interpretazione dell'iscrizione CIL IX $3173=I L S 5642$. Historia 32.4 (1983) 484-507, here $500 \mathrm{ff}$.

${ }^{2}$ See PotTS, C. R.: Religious Architecture in Latium and Etruria, C. 900-500 BC. Oxford 2015, 126 (for Satricum); BROWN F. E. - RICHARDSON, E. H. - RICHARDSON JR., L.: Cosa II: The Temples of the Arx. Memoirs of the American Academy in Rome 26 (1960) 10-14; BONGHI JovinO, M.: Tarquinia etrusca. Tarconte e il primato della città. Roma 2008, 17-20; ColiviCCHI, F.: Il "mundus" di Clepsina e la topografia di Cerveteri. Scavi dell'Università di Perugia nell'ex Vigna Marini-Vitalini, campagne 2001-2002. Science and Technology for Cultural Heritage 12.1-2 (2003) 11-42; CoLIVICCHI, F.: The mundus of Caere and early Etruscan Urbanisation. In KEMEZIS, A. M. (ed.): Urban Dreams and Realities in Antiquity. Remains and Representations of the Ancient City. Leiden-Boston 2014, 46-68, here 55.

${ }^{3}$ Concerning where we find the mention of a Cerealis mundalis, who likely was a priestess who had to perform the rite of the mundus Cereris, see Dognini, C.: Mundus. Etruria e Oriente in un 'istituzione romana. Galatina 2001, 35.

${ }^{4}$ DEVIJVER - VAN WONTERGHEM (n. 1)

${ }^{5}$ MARAstoni, S.: Il mundus di Grumentum? In Mastrocinque, A. (ed.): Grumentum romana. Convegno di studi, Grumento Nova (Potenza), salone del castello Sanseverino, 28-29 giugno 2008. Moliterno 2009, 234-250.

${ }^{6}$ COARELli F.: Ara Saturni, Mundus, Senaculum. DArch 9-10 (1976-1977) 346-377, here 60. 
Rome: while the Comitium is the symbolic meeting-place of the assemblies of the populus, the mundus is a monument that reminds the foundation of the City and its communication with its gods. According to Mastrocinque, ${ }^{7}$ only this mundus really existed, even though another mundus was traditionally put on the Palatine, in accordance with the Augustan ideology.

To try sum up, therefore, according to the ancient authors, there was a holy place in Rome, called mundus, or probably mundus Cereris (Festus, p. 142 L.), which connected to the worship of the underworld gods. It was a domed structure, large enough for a man to enter (Festus, p. $157 \mathrm{~L}$.). In its ground floor, there was an opening leading to a chamber or shaft, which was sacred to the Di Manes, and opened only on three days, as mentioned above, which were regarded as unlucky. ${ }^{8}$

Indeed, as Mastrocinque has clearly explained, the ancient Romans believed some specific rituals aimed at making an agreement with three different kind of deities had to be done that in a specific order to find a town. In fact, according to Varro, the Roman deities were ascribed to three different dominions: heaven, earth, and underworld (di superi, terrestres et inferi). The relationship between the Romans and their gods was grounded on the pax deorum; to assure this pax it was necessary to comply with some rules that need to be established at the time of the foundation. ${ }^{9}$ In this case, the di terrestres were conceived as deities linked to a specific territory (see the institution of the asylum and the pomerium founded by Romulus). The agreement with the underworld gods was precisely made through the creation of a mundus. From many sources, we learn that firstlings and a handful of terrain brought by each citizen were thrown into the new mundus. This ritual gesture is well known within ceremonies for Demeter. If we have to think of a deity capable of mediating between heaven, earth and underground, Demeter/Ceres, together with her daughter Persephone/Proserpina, would be the perfect choice: She belongs to the group of the "Olympian" goddesses, but she descends to earth to look for her kidnapped daughter, who, at the very end, will spend half of the year underground with her husband Hades/Pluto. Moreover, she taught men how to cultivate grain and she presides over the seasonal cycle. She is also a mysteric goddess. All these features make Demeter very similar to Cybele, as we will see.

\footnotetext{
${ }^{7}$ MASTRocinQue, A.: Roma quadrata. MEFRA 110 (1998) 681-697, here 694. According to F. MARCATiLli (Cerere e il "mundus" del Circo Massimo. In ANGiolillo, S. ET AL. (eds): Le perle e il filo. A Mario Torelli per i suoi settanta anni. Venosa 2008, 195-223), there were two mundi, and the mundus Cereris was probably in the Circus Maximus, as confirmed by some representations on sarcophagi.

${ }^{8}$ Varro (ap. Macrob. Sat. 1. 16. 18) also says mundus cum patet, deorum tristium atque inferum quasi ianua patet (cf. Serv. ad Verg. Aen. 3. 134: quidam aras superorum deorum voluit esse, medioximorum, id est marinorum focos, inferorum vero mundos). See PLATNER, S. B.: A Topographical Dictionary of Ancient Rome. Completed and revised by T. Ashby. Oxford-London 1929, 346-348.

${ }^{9}$ To quote Sheid's famous words, gods were somehow Roman citizens, but of higher lineage and more powerful. The religious sphere was not separated from the political one. See SCHEID, J.: La religione a Roma. Roma-Bari 1983, 61 ("Gli dei, in un certo qual modo, sono cittadini"). Cf. MASTROCINQUE, A.: Religione e politica: il caso di Bona Dea. In CECCONI, G. A. - GABriELli, C. (eds): Politiche religiose nel mondo antico e tardoantico. Bari 2011, 165-172.
} 
At least, theoretically, each Roman colony in Italy could have been founded in the same way the Urbs was, and therefore each colony would have had its own mun$d u s .{ }^{10}$ However, as Marastoni has observed, from this inscription from Consilinum, as well as from the one from Corfinium, we learn that a mundus can also be built after the foundation of a city, for instance in a period of building renewal or in case of a "symbolic" re-foundation after a transformation, as in the case of Cerveteri after its transformation into a praefectura. ${ }^{11}$ In this way, we can explain why the mundus in Consilinum was built after the foundation of the city with the money of two wealthy women. This kind of mundi, which were erected during the late-republican or the imperial period (Consilium, Corfinium, possibly Grumentum), seem to have a particularly strong astral connotation. ${ }^{12}$

In this regard, we can assert that the word mundus as a sacred place has significantly changed over centuries: at a first stage, as we have just said, this word indicates a plethora of sacred places connected with the idea of foundation, underworld and agriculture. Subsequently, starting from the late-republican period, it can be associated with a cultic place connected with a new cosmic and astral theological vision of the divine world, influenced by the Neopythagoreanism and perhaps by some Etruscan doctrines. $^{13}$

According to Cristiano Dognini, who wrote a book on the meaning of the mun$d u s$, with a particular focus on the etymological aspects, ${ }^{14}$ this concept incorporated, as a Roman institution, strong Etruscan and Oriental influences. He puts forwards the hypothesis of a not exclusively commercial and cultural contact between the Etruscans and the Mesopotamian world. This contact would not be limited to the so-called Orientalizing phase. Without entering here into the complex problem of Etruscan origins, Dognini points out that similarities between the Etruscan and the Near Eastern cultures are so numerous that it is likely to think, at least as far as the mundus is concerned, of previous contacts before the arrival of Etruscans in Italy. ${ }^{15}$

This is particularly interesting in my opinion, since, as I have tried to argue in some previous works, in Southern Italy, and above all in Sicily, Cybele's cult preserved features closer to the Anatolian religion, because she had arrived here directly, before the Greek colonization. ${ }^{16}$ This is evident - brutally simplifying - in the impor-

\footnotetext{
${ }^{10}$ The comparison with Cosa seems to confirm this, see MASTROCINQUE: Roma quadrata (n. 7) 694; MASTROCINQUE, A.: La fondazione di Roma e l'asilo. Index. Quaderni camert di studi romanistici 38 (2010). See also COLIVICCHI: The mundus (n. 2) 63.

${ }^{11}$ COLIVICCHI: The mundus (n. 2) 64: "It is natural that the new founder of the city, the Roman praefectus of Etruscan origin C. Genucius Clepsina, put his mark - and his name - in this crucial space".

${ }^{12}$ In fact, in MARASTONI's (n. 5) opinion, in this period mundi could be built without graves or tracks, like in the case of the Grumentum's one.

${ }^{13}$ MARASTONI (n. 5) 243-249. For the This Pythagorean or Pythagorizing theories in relation with the mundus and the Comitium, see infra.

${ }^{14}$ DOGNINI (n. 3).

${ }^{15}$ Dognini (n. 3) $82 \mathrm{f}$.

${ }^{16}$ PEDRUCCI, G.: I santuari rupestri Metroaci fra Sicilia e Anatolia. RSA 35 (2005) 165-179; PEDRUCCI, G.: Il culto di Cibele e la Sicilia. Santuario rupestri nell'iconografia della dea. Roma 2009. As suggested below (n. 62), it is likely that two different goddesses had existed, at least in certain places and certain periods.
} 
tance of rocks in the cult, especially in the connection between fertility and death, literally, through the Earth, by penetrating the Earth itself. We will also return to this. We have already underlined that the mundus can be a cave or a crack in the rock. The link between cracks/caves and the netherworld is well known. ${ }^{17}$ To suggest a "direct" passage from Sicily to Campania based on the documentation we have is, of course, quite risky; but I would like to stress some interesting features of the Metroac cult, which are not typical of the Hellenized version of the goddess.

Going back to the mundus, our main aim is not that of giving an exhaustive definition of what it was or looked like, but to understand its possible association with Cybele and Attis. The only link we know is with Ceres, who is usually identified with the Greek Demeter. To be more precise, in the Imperial period, the association between Ceres and Demeter is clear and obvious, but during the ancient phases of Rome it has not completely taken place. ${ }^{18}$ Ceres's own chthonian and fertility aspects, however, are quite evident if we think of her link with the so-called Mater Larum. ${ }^{19}$ The connection itself between maternity and death is extremely interesting, and not unusual and contradictory (see for instance her presence in some defixiones). ${ }^{20}$

Therefore, to answer briefly our first question, what?: A mundus is the junction point between the dead and living people, between the underworld and the sky. More precisely, a mundus Cereris (and other kinds of mundi likely exist), described as divided into two parts, had a vaulted ceiling, was hollow so that a person could enter it, and no altar above is mentioned. According to Dognini, ${ }^{21}$ only the upper part was accessible, whilst the other one was always closed. It is likely that an underground chamber existed; it is hard to say if it was accessible. Chthonian and agrarian aspects here overlap. Moreover, both Greek and Roman sources seem to have never doubted the Etruscan origin of the mundus, and often associated it with an Etruscus ritus. Dognini states that this is particularly evident in the idea that the macrocosm (sky) and microcosm (well) correspond; and also in the four-part division of mundus, which is typical of the Etrusca disciplina. ${ }^{22}$

${ }^{17}$ Aen. 8. 568-571. Dognini (n. 3) 32. Indeed, wells, cracks and caves are important in Demeter's cult, too, see SfAmeni GaSPARRo, G.: Misteri e culti misterici di Demetra. Roma 1986, 270.

${ }^{18}$ According to Marcatilli (n. 7) 195, Demeter was worshipped in Rome (probably in Valle Murcia), before the 5 th century BC.

${ }^{19}$ MASTROCINQUe, A.: Lucio Giunio Bruto. Trento 1988, $140 \mathrm{f}$.

${ }^{20}$ See infra.

${ }^{21}$ DOGNINI (n. 3) 41.

${ }^{22}$ Dognini (n. 3) 63-75. I would like to sum up the entire issue with Dognini's words: "una prima acquisizione [...] è il valore di base del sostantivo mundus, che [...] a dispetto delle apparenze, non è stato influenzato, se non in età imperiale, dal greco kosmos, giacché tutte le accezioni di quest'ultimo riconducono al concetto di 'ordine' mutuato dal lessico politico-militare, mentre le origini del latino mun$d u s$ sono affatto diverse. I principali significati di questo lemma erano, infatti, in origine quelli di 'volta celeste' - e per estensione 'universo' -, 'ornamento femminile' e 'pozzetto infero'. Tutte realtà che hanno in comune fra loro solo la forma circolare (anche mundus muliebris, se si pensa a una collana, a un torques o un orecchino). Solo in un secondo tempo mundus è stato utilizzato come traduzione di kosmos, visto che condivide con questo termine i significati di 'universo' e di 'ornamento muliebre'. Non si tratta, però, di due lemmi isoglossi, e mi sembra peraltro improprio parlare di calco semantico, salvo nelle versioni latine del Nuovo Testamento e negli autori cristiani, in cui mundus assume la medesima connotazione negativa che ha il greco kosmos, inteso come mondo terreno in contrapposizione a quello divino" 
To whom was the mundus sacred? Who is Attis?

As we have just seen, in primis, the main deity associated with the mundus is Ceres/ Demeter. The link with her daughter Kore/Persephone is important, even though in this specific case probably not essential. The almost perfect correspondent for Demeter would be Cybele: they are often juxtaposed, sometimes even switched in our sources, from Euripides ${ }^{23}$ to Julian, who addresses the Mother of the gods as Cybele, Demeter and Deo; ${ }^{24}$ but the mundus in Consilinum is sacred to Attis, not Cybele. If we think of Demeter/Persephone and Cybele/Attis as mystic/mysteric couples, ${ }^{25}$ Attis would be the parallel correspondent for Persephone. So, something apparently does not match.

At this point, we should consider who Attis is.

There are many mythological variations, which can be grouped into two versions: The so-called Phrygian one (Ovid, Pausanias and Arnobius) concerning his self-castration and death, and the Lydian one (Herodotus) in which he is killed by a boar. $^{26}$

(p. 79). See also Dognini, C.: Kosmos e Mundus due concezioni a confronto. In Dognini, C. (ed.): Kosmos. La concezione del mondo nelle civiltà antiche. Alessandria 2002,81-98. Kosmos only in a second context means universe, originally it means order (with the idea of perfection, and for the ancient Greeks the universe is grounded on a perfect order). The Romans are notoriously more pragmatic; therefore, they describe the universe simply as it appears, that is as something circular.

${ }^{23}$ Sfameni GasparRo, G.: Connotazioni meotroache di Demetra nel coro dell'Elena (v. 10311365). In De Boer, M. B. - EdRIDGE, T. A. (eds): Hommages à M. J. Vermaseren. Vol. III. Leiden (1978) $1148-1187$.

${ }^{24}$ PEDRUCCI: Il culto (n. 16) 21.

${ }^{25}$ We consider Ugo Bianchi one of the main authorities in this field; in particular, the fundamental distinction among mystic, mysteric, and mysteriosophic (e.g., BIANCHI, U.: Initiation, mystères, gnose (Pour l'histoire de la mystique dans le paganisme gréco-oriental). In Bleeker, C. J. [ed.]: Initiation. Leiden 1965, 154-171; BIANCHI, U.: The Greek Mysteries. Leiden 1976; BIANCHI, U.: Mysteria Mithrae. LeidenRoma 1979). For an exhaustive overview on studies about mysteries, see CASADIO, G. - JOHNSTON, P.: Introduction. In CASADIO, G. - JOHNSTON, P. (eds): Mystic Cults in Magna Graecia. Austin 2009, 1-29, esp. 2-4 for Bianchi's work. Moreover, as brilliantly shown by CASADIO, G.: The Failing Male God: Emasculation, Death and Other Accidents in the Ancient Mediterranean World. Numen 50 (2003) 231268 , the category "deities subject to vicissitude" (typical terminology by Bianchi, see for instance in Mysteria Mithrae p. 5) or "dying and raising gods" are still valuable for the work of the historian of religions. Unfortunately, Ugo Bianchi is often neglected by other scholars, such as BREMMER, J. N.: Imperial Mysteries. In Les "mystères » : questionner une catégorie [Mètis - Anthropologie des mondes grecs anciens 14]. Paris 2016, 21-34, who mention only Franz Cumont and Walter Burkert (notoriously in Ancient Mystery Cults, Cambridge-London 1987) as leading scholars in this field. See also BREMMER, J. N.: Initiation into the Mysteries of the Ancient World. Berlin-Boston 2014.

${ }^{26}$ Hdt. 1. 34-45; Paus. 7. 17. 9 ff.; Arn. Adv. nat. 5. 5-7; Ov. Fasti 4. 221-244. In addition, there is the so-called "euhemeristic" version of Diodorus, 3. $58 \mathrm{f}$. See Cosi, D.: La simbologia della porta nel Vicino Oriente. Annali della Facoltà di Lettere e Filosofia. Università di Padova 1 (1976) 113-152; VERMASEREN, M. J.: Cybele and Attis, the Myth and the Cult. London 1977; FASCE, S.: Attis e il culto Metroaco a Roma. Genova 1978; ThOmAS, G.: Magna Mater and Attis. ANRW II 17.3 (1984) 1500-1534; NÄSSTRÖM, B.-M.: The Abhorrence of Love. Studies in Rituals and Mystic Aspects in Catullus' Poem of Attis. Stockholm 1989; PODEMANN SöRENSEN, J.: The Myth of Attis: Structure and Mysteriosophy. In Podemann Sörensen, J. (ed.): Rethinking Religion. Copenhagen 1989, 23-29; ROLLER, L. E.: In Search of God the Mother. The Cult of Anatolian Cybele. Berkeley - Los Angeles - London 1999, 237-261; LANCELLOTTI, M. G.: Attis. Il caro estinto. In Xella, P. (ed.): Quando un dio muore. Morti e assenze divine 
As we can see, Attis's death is the common denominator. ${ }^{27}$ The attempt of Pausanias (and that of Arnobius) to modify this sorrowful conclusion by reviving him is crucial. Although this does not actually take place, a form of survival after death is indeed accorded to him: his body neither rots at all nor decays, his hair continues to grow and a finger remains in motion. So, if we cannot speak of a return to life and much less of a "resurrection", the mythical tradition attested by the two authors has an outcome which, even if it is characterized by pathos and mourning, gives Attis a positive prospect, since he is saved from complete annihilation. In this manner, he obtains a subsistence beyond death, or, to say it with Gasparro's words, a subsistence "in death". After analyzing some sources that stress Attis's connection with arborescent and florescent vegetation, Gasparro also points out his pertinence to the category of those superhuman figures whose vicissitudes of presence and absence can be seen as a support and divine guarantee of the altering rhythm of vegetation (the so-called "fertility gods", typical of Near East mythologies) ${ }^{28}$ In particular, some Christian authors (Eusebius, Agostinus, Firmicus Maternus: The latter uses the verb revivere, but it is just a loan word from the Christian terminology), ${ }^{29}$ referring to the interpretations of certain learned pagans, trying to prove that the naturalistic references in myths and religious traditions of paganism are essential: Changes that Attis's myths undergo during the late Imperial Period is what interests us most, as we will see.

Despite many clear differences, analogies with Demeter and Persephone are undeniable. For instance, in the euhemeristic version of Diodorus, a pestilence fell upon human beings throughout Phrygia and the land ceased to bear fruit, and when people asked the god how they might rid themselves of their ills he commanded them to bury the body of Attis (who is dead, of course) and to honor Cybele as a goddess. So, there is a crisis caused by the absence of the goddess, marked by a sterility of animals and earth, which threaten the human race with extinction. The crisis is over when the goddess receives some kind of "compensation" for her "in vicissitude" partner's loss (see also Ishtar-Tammuz). In contrast with the Demetrian myth, in which we find Persephone's alternating situation, the case of Attis knows neither a periodic "return" nor a form of "revival": he dies once for all. Nevertheless, the dead Attis is annually commemorated by the funerary rites of lamentation performed by the Phrygians be-

nelle antiche tradizioni mediterranee. Verona 2001, 115-150; LANCELLOTTI, M. G.: Attis. Between Myth and History: King, Priest and God. Leiden 2002; NAUTA, R. R. - HARder, A. (eds): Catullus' Poem on Attis. Text and Contexts. Leiden 2005; BERNDT-ERSÖZ, S.: Phrygian Rock-cut Shrines. Structure, Function, and Cult Practice. Leiden-Boston 2006; BERNDT-ERSÖZ, S.: Phrygian Rock-cut Step Monuments: An Interpretation. In Anatolian Iron Ages 6. The proceedings of the Sixth Anatolian Iron Ages Colloquium held at Eskişehir, 16-20 August 2004. Leuven 2007, 19-39; BORGEAUD, P.: La madre degli dei. Da Cibele alla Vergine Maria. Brescia 2006, Borgeaud, P.: La Mère des dieux. De Cybèle à la Vierge Marie. Genève 1996.

${ }^{27}$ LANCELLOTTI: Attis. Il caro estinto (n. 26) 127. She states that we can speak of resurrection: Zeus explicitly denies it to him. On the contrary, his death is the pivotal aspect of this cult; Cybele herself establishes funerary rites for him.

${ }^{28}$ SfAMENI GASPARRO, G.: Soteriology and Mystic Aspects in the Cult of Cybele and Attis. Leiden 1985. 43ff. Contra: LANCELLOTTI: Attis. Il caro estinto (n. 26) 130f.: The pine and the violet are symbols of death, Attis's myth is based on anti-generative features.

${ }^{29}$ SFAMENI GASPARRO: Soteriology (n. 28) $46 \mathrm{ff}$. 
fore his images. In this manner, he is felt to be present in a ritually effective way, and nature order returns after its disruption. The establishment of the rite, in which the commemoration of Attis and Cybele's pathos is crucial, appears as the conclusive moment of the whole episode and, repeated annually, it guarantees the regular rhythm of the seasonal cycle.

The so-called Metroac cult, therefore, has chthonian, funerary, agrarian, and fertility connotations. Possibly, due to its Anatolian origins, in comparison with Demeter's cult, Cybele's cult bears a stronger link with rocks, with caves, and with the earth as giver of life and place for death. This latter aspect is clearly visible also in Cybele's mention in the defixiones. ${ }^{30}$

So far, the reason for choosing Cybele instead of Ceres/Demeter for a mundus would be quite evident. We have to understand, also, why Attis, instead of Cybele. In order to answer this, the focus on when and where is crucial.

The first mention of Attis in Latin sources is in Catullus, nevertheless a cult on the Palatine is traceable to the 2 nd century $\mathrm{BC} .^{31}$ Starting from the second to the early 3rd century CE, Attis's importance in Rome as an independent cult figure developed greatly, as witnessed by major shrines to him in Ostia. ${ }^{32}$ As an independent figure, we have to take onto consideration how extensively the Attis's myth served as a metaphor in late antique philosophical and religious discussions. Now the most difficult question is why Attis's myth was chosen as the vehicle for such discussions.

When is the Consilinum's inscription dated? Where was it found? Philosophical connotations of Attis's cult in late antiquity

The inscription is dated to the 3rd century CE and speaks of a return, and of Attis's "transformation" as a symbol of life after death. ${ }^{33}$ In late antiquity, Attis becomes symbol of life after death, in some cases, even of resurrection; even though the development of a solar theology concerning his figure and of the so-called Attis platonicus ${ }^{34}$ are later, extremely palimpsestic phenomena, but these ideas could have already been in nuce, especially in Southern Italy, where philosophical currents such as Orphism and Pythagorism, in addition to Platonism, had a notoriously long-lasting tradition.

\footnotetext{
${ }^{30}$ Pedrucci: Il culto (n. 16) 37-40; ŚMiejová Kellová, M.: Magic Use of Mother's Name. Humans, Goddesses, and Curse Tablets. In PAsche Guignard, F. - PedruCCI, G. - SCAPINI, M. (eds): Motherhood(s) and Polytheisms - Maternità e politeismi. Bologna 2017 (forthcoming).

${ }^{31}$ See in particular the little statues of Attis found on the Palatine: PENSABENE, P.: Nuove indagini nell'area del tempio di Cibele sul Palatino. In BIANCHI, U. - VERMASEREN, M. J. (eds): La soteriologia dei culti orientali nell'Impero Romano. Leiden 1982, 68-108, here $86 \mathrm{f}$. It is interesting to note that also in Northern Italy we have traces of a cult of Attis at the beginning of the 1st century BC: MASTROCINQUe, A.: Culti e santuari del Nord-Ovest d'Italia. Rassegna di Studi del Civico Museo Archeologico e del Gabinetto Numismatico di Milano. Notizie dal Chiostro 63-64 (1999) 114-115.

${ }^{32}$ The dedications mostly date II century CE, during the reign of Antoninus Pius, who himself was greatly interested in the cult, see VERMASEREN: Cybele (n. 26) 62.

${ }^{33}$ If we follow the first hypothesis of reading, see supra.

${ }^{34}$ Elaborated by Julian and Sallustius, see SFAMENI GASPARRO: Soteriology (n. 28) 62. For Julian's Oration to the Mother of the Gods, see also Cosi, D.: Casta Mater Idaea. Giuliano l'Apostata e l'etica della sessualità. Venezia 1986. Cf. Mithra platonicus (see e.g., TURCAN, R.: Mithras Platonicus: Recherches sur l'hellenisation philosophique de Mithra. Leiden 1975).
} 
In this regard, the ceremony of the Hilaria might be particularly enlightening: the mundus, in fact, might be connected to the (mysteric?) rites in honor of the dead Attis who, during the Hilaria, was probably carried in an underground chamber for lamentations, before his new life (which does not necessarily mean resurrection).

The day of this celebration was the first after the vernal equinox, or the first day of the year, which was longer than the night. The winter with its gloom had passed away, and the first day of a better season was spent in rejoicing. The connection of the chosen day with the sun and the nature cycle, the rebirth of nature after the winter is crystal clear.

The manner of this celebration during the time of the Republic is unknown, except that Valerius Maximus (2. 4) mentions games in honor of the Mother of the Gods. Under the Empire, many sources speak of the lavatio as the final part of the Phrygian funerary ritual. ${ }^{35}$ But it is only starting from the 3rd-4th century CE that we have witnesses concerning a joyful ceremony called the Hilaria, which was celebrated after the grief but before the lavatio. Therefore, it seems to be difficult to establish a "direct" link between the mundus in Consilinum, which dates to the 3rd century CE, and the Hilaria; nevertheless, in the Argonautica by Valerius Flaccus (8. 239-242), we read of manifestations of joy (festae taedae) after the lavatio. Moreover, according to Sfameni Gasparro, it is possible that at least from the 1st century CE, expressions of joy were part of the Roman cult of Cybele. Only later, however, perhaps in the Antonine period, were they institutionalized in a ceremony performed in a particular day, between the mourning and the lavatio. As we have already pointed out, such manifestations of joy, as well as the official ceremony of the Hilaria, do not express the idea of resurrection, but of survival from "total" death, the idea that his disappearance is neither total or ultimate. At least until Firmicus Maternus (Err. prof. rel. 3. 1), who seems to speak of resurrection (quem Paulo ante sepelierant revixisse iactarunt) in $346 \mathrm{CE}$ (that is, 8 years before Filocalus' calendar and the first official mention of the Hilaria). ${ }^{36}$ Sallustius describes the Hilaria as a climb back (epanodos) up to the gods. Other possible connections with the idea of re-birth can be found, according to Cosi, in Attis's presence on funerary monuments, especially on sarcophagi, and in his role as psychopomp.

A devotee of Attis in $376 \mathrm{CE}$, who made a taurobolium for him, states that he was in aeternum renatus. This is an unicum. According to Dario Cosi,${ }^{37}$ this does not indicate a resurrection and new life, that is salvation, but a new start, the beginning of a new life, or of a new cycle of one's life. Cosi quotes Sallustius Philosophus (4), who mentions milk libations for those who were re-born during Attis's mysteries (which is strictly consistent with the definition of mysteric religion as proposed by Ugo Bianchi). ${ }^{38}$

\footnotetext{
${ }^{35}$ SFAMENI GASPARRO: Soteriology (n. 28) $56 \mathrm{ff}$.

${ }^{36}$ BORGEAUD: La madre (n. 26) 147.

${ }^{37}$ COSI: La simbologia (n. 26) 69-71.

${ }^{38}$ COSI: La simbologia (n. 26) 52, quoting BIANCHI: Initiation (n. 25).
} 
Moreover, we should pay attention to who this devotee was: a pater patrum in Mithra's mysteries, a priest of Hecate ${ }^{39}$ and an archibucolos of Dionysus/Liber: at least at the end of the 4th century a certain confusion and a large demand for a more direct relationship with the gods seems to exist.

If we take into consideration the taurobolium, where is important, too. The first mention of a taurobolium to Venus Coelestis is from Pozzuoli and dates to 134 CE. ${ }^{40}$ Under Antoninus Pius we find a rite for the Mother of the Gods and Attis in the form we already know: It was a private and aristocratic initiation rite, performed for the salus of the Emperor. Salus was often associated with words such as incolumitas, victoria and reditus. ${ }^{41}$

Concerning the mysteric ceremony, Firmicus Maternus (Err. prof. rel. 18. 1) and Clemens Alexandrinus (Protr. 2. 15. 3) describe the most important part of it: A sacred meal, a kernophoria (carrying of sacred tables with carved depressions for the offerings) and a third problematic step, in which could be mentioned an underground nuptial chamber to celebrate the union with the goddess or the innermost cell of the temple. ${ }^{42}$ This could be consistent with the underground chamber in the mun$d u s$, which, in my opinion, might be seen as a sort of womb (reversed, in the sense of an upside-down, womb?). The idea of literally penetrating the goddess through the rock might come from Anatolia, the county of origin of Kubaba/Matar/Cybele, ${ }^{43}$ as we have seen. In Vermaseren's opinion, ${ }^{44}$ who follows Festugière, Clemens's phrase vं

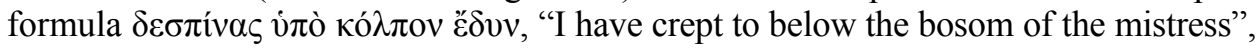
i.e. penetrated as far as the womb of Persephone or Kore, who sits enthroned in the Underworld. It would be possible, therefore, to translate the Orphic symbol by "I have descended into the bosom of the mistress", which clearly implies a descent into the Underworld. This is the highest initiation ( $\tau \varepsilon \lambda \varepsilon \tau \eta \eta \eta)$, and it will gain the mystes a better

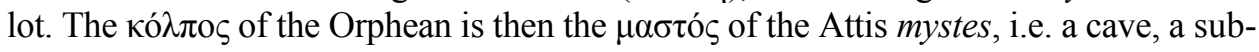
terranean or hidden space in or near the temple. Moreover, Firmicus's text concerns a person who had been dedicated to die (moriturus), and after that pronounce the symbolum or formula in order to be admitted in the innermost part of the temple. On the analogy of other mysteries, the Attis mystes also knew this so-called voluntary death. In this underground womb, he might perform this temporary death in order experience re-birth into a new life.

Another important aspect to take into account is the Neoplatonist and gnostic evolution of Attis's myth. As Dario Cosi wrote, under the influence of powerful (n. 7) 209f.

${ }^{39}$ Hecate might be represented, standing on a mundus, on a Vatican sarcophagus, see MARCATILLI

${ }^{40}$ BorgeAUD: La madre (n. 26) 172.

${ }^{41}$ Cosi: La simbologia (n. 26) 68.

${ }^{42}$ Cosi: La simbologia (n. 26) 56-59.

${ }^{43}$ COSI: La simbologia (n. 26); BERNDT-ERSÖZ: Phrygian Rock-cut Shrines (n. 26); BERNDTERSÖZ: Phrygian Rock-cut Step Monuments (n. 26) 19-39; PEDRUCCI: I santuari (n. 16); PEDRUCCI: Il culto (n. 16).

${ }^{44}$ Vermaseren: Cybele (n. 26) 117. Festugière, A. J.: Les mystères de Dionysos. RBi 44 (1935) 381-396. 
philosophical (especially Neo-Platonic ones), and religious (rising of Christianity and subsequent imitation by opposition) suggestions, the mysteriosofic theory concerning resurrected Attis, savior of himself and potential savior of his devotees became quite popular. ${ }^{45}$ In fact, Julian the Emperor $(330-363 \mathrm{CE})^{46}$ describes Attis as a semi-god, son of the third demiurge and creator par excellence, who descends into the lowest matter and falls into a perpetuity of generation (he was in love with a nymph, who symbolized nature and (re)generation), ${ }^{47}$ the essence of that prolific and demiurgic intellect which generates all things even to the lowest matter, and which contains in itself all the reasons and causes of material forms, and he stops his infinity (and saves himself) through the castration. We have already mentioned that, according to Sallustius the philosopher, the Hilaria were a return to the gods. Damascius (458-538 $\mathrm{CE}$ ), known as "the last of the Neoplatonists", alludes to the fact that Attis's initiates can obtain a form of "salvation from Hades", as Attis himself did. ${ }^{48}$ Hippolytus of Rome (170-235 CE), ${ }^{49}$ reporting some Naassenic Gnostic beliefs, describes Attis as a symbol of the soul that is buried in the body and needs to escape from the material word and ascends to heaven. ${ }^{50}$ Finally, within a religious and philosophical trend we can label as "solar theology", Attis becomes the symbol of the Sun. ${ }^{51}$

Another philosophical trend particularly popular in Southern Italy was Orphism. As analyzed by Bernabè, ${ }^{52}$ the Orphic image of life in the realm of Persephone as a model of a perfect world for special initiates, where concord and happiness rule with the characteristics of a utopia constructed, like most of them, as a "negative" foil, an antithesis of the imperfect life in our world above. This Orphic utopia, however, does not try to criticize worldly institutions nor to propose a model to modify them. It is not envisaged as a mere exercise of the imagination, but rather purports itself as an

\footnotetext{
${ }^{45}$ Concerning Christian influences starting from Antoninus Pius and Marcus Aurelius' Reigns, BORGEAUD: La madre (n. 26) wrote: "se certe influenze o attrazioni, o altro ancora, hanno svolto un ruolo indubitabile, ciò è avvenuto nei due sensi e fu reso possibile dall'esistenza di una comunanza di interessi. Piuttosto che a un'imitazione occorre pensare a delle interferenze, che risultano verificabili e tuttavia si esercitano in un clima pluralista e conflittuale, e secondo le modalità e i procedimenti dalla controversia e non dell'assimilazione."

${ }^{46}$ Or. 5, in part. 167a ff. Cf. SiMÓN, F. M.: On Bulls and Stars: Sacrifice and Allegoric Pluralism in Julian's Times (221-236). In MASTROCINQUe, A. - GIUFFrÉ SCIBONA, C. (eds): Demeter, Isis, Vesta, and Cybele: Studies in Greek and Roman Religion in Honour of Giulia Sfameni Gasparro. Stuttgart 2012. Marco Simón comments on the two faces of the emperor's piety. On the one hand, it was traditional polytheism, but on the other hand, it was the philosophical monotheism of Neoplatonism. See also Cosi: Casta Mater (n. 34).

${ }^{47}$ Cf. Sallust. Phil. 3. 33.

${ }^{48}$ SFAMENI GASPARRO: Soteriology (n. 28) 62.

${ }^{49}$ Haer. $5.7 \mathrm{ff}$.

${ }^{50}$ Cf. LANCELlotti: Attis. Il caro estinto (n. 26) 119-151.

${ }^{51}$ Arn. Adv. Nat. 42; Macrob. Sat. 1. 21. 9; Mart. Cap. 2. 192; Julian. Or. 5.168c; Pocl. Hymn. Sol. 25. See SFAMENI GASPARRO: Soteriology (n. 28) 61. Cf. BRACCO (n. 1) who put the mundus in connection with the winter solstice. We might also note that, if Attis does have chthonian and funerary connotations, which are evident in his connection with the mundus, and he lives in the (highest) sky, according to the authors we just mentioned, he has undergone a transformation, which is similar to the one Mithras undergoes, from underground to ipercosmic god (cosmocrator).

${ }^{52}$ Bernabé, A.: A Brave Netherworld: The Orphic Hades as Utopia. In MASTROcinQue - GiUfFRÉ SCIBONA (n. 46) 10-23.
} 
alternative reality, situated in another world, the world that will only be accessed after death by a group of privileged people, namely the initiated. This existence in Hades is considered to be so real that it will eventually be defined as true "life", in contrast to life in this world, which is qualified as "death". 53 Those aware of the divine origin of their souls and of the reasons for the punishment suffered by human beings, who ritually prepare themselves for the privileged place and behave fairly and piously in this life, and decide to leave behind their earthly identity, will merit, at the end of a long series of reincarnations, recognition and compensation. According to these ideas, the order (kosmos) is re-established and the world acquires sense for the initiated who detach themselves from "common" values.

It is worth noting the kind of sources Bernabè used: Passages from gold tablets found in Magna Graecia and other places, bone tablets from Olbia, fragments of poems attributed to Orpheus, some evidence from Plato, as well as from other ancient authors, and ceramic representations from the South Italic area, particularly from Apulia. In this regard, I would like to point out that we have a gold tablet from Turi (Calabria) in which Korra (possibly Kore) is called kubeleia, which derives from Kybele/Cybele. Besides, Demeter is mentioned, as well. In this area, already around the early 5th-6th century BC, some sort of juxtaposition between Cybele and the couple Demeter/Kore seems to have been well established. ${ }^{54}$

We have finally arrived at the last tessera of this really complex mosaic: The Pythagorean influences. Between the end of the 2nd century and the beginning of the 1 st century CE, the mundus in Rome was monumentalized by the building of a monopteros, that made it similar to the omphaloi with an aedicule present on the Etruscan urns. ${ }^{55}$ According to Michel Humm ${ }^{56}$ starting from the end of the 4th century BC, it would have received a Pythagorean interpretation that would have assimilated it to a symbolic representation of the cosmos. This Pythagorean or "Pythagorizing" interpretation could have been the consequence of the circular form adoption of the Comitium and the mundus would have expressed its cosmic dimension.

Pythagorean theories began to be quite popular very early in Rome, at least from the time of Ennius's plays, in which we can find the divinization of the sky, which is depicted as a vault. As a possible consequence, in Rome and in central-Southern Italy we find an increasing number of circular buildings and caves with a symbolic cosmic

${ }^{53}$ In the gold tablet Thurii II B 1, the initiate says: "I have fallen as a kid into milk". It was published by PUGLIESE CARRATELli, G.: Le lamine d'oro orfiche: istruzioni per il viaggio oltremondano degli iniziati greci. Milano 2001, 103-111, 114-121. In particular, p. 109: "la formula es gal'epeton, 'verso il latte', viene solitamente tradotta 'caddi nel latte' e interpretata come una metaforica descrizione della beatitudine finale ottenuta dal mystes: mi sembra una formula rituale che, ora pronunziata da un nume, ora dall'iniziato, annunzi con l'immagine del neonato che cerca d'impeto il latte (come indica la variante tessalica eis gala ethores) una spirituale rinascita, sotto il segno di Dioniso, e il desiderio di 'vital nutrimento': esplicita in questo senso è d'altronde la dichiarazione iniziale delle due lamine tessaliche: 'ora moristi e ora nascesti'”. For milk related to the initiate's rebirth, see Sallustius Philosophus, cf. n. 47.

${ }^{54}$ PEDRUCCI: Il culto (n. 16) 69-71 (also for the Derveni papyrus).

${ }^{55}$ MARAstONi (n. 5) 242.

${ }^{56}$ Humm, M.: Le mundus et le Comitium: représentations symboliques de l'espace de la cité. Histoire urbaine 10.2 (2004) 43-61. 
meaning. ${ }^{57}$ Moreover, in the same period, the elaboration of a new vision of the soul (which becomes immortal) in the afterlife is promoted. Ennius was born in the Messapic Rudiae, near Taranto. Another philosopher who influenced Roman ideas in this period was Bossius from Cuma. ${ }^{58}$

Later revivals of Pythagorean doctrines led to what is called Neopythagoreanism or Neoplatonism. Central to the Neopythagorean thought was the concept of a soul and its inherent desire for a unio mystica with the divine.

Neopythagoreans emphasized the fundamental distinction between the soul and the body. The soul must be freed from its material surrounding. In this system can be distinguished not only the asceticism of Pythagoras and the later mysticism of Plato, but also the influence of the Orphic mysteries and of the Oriental philosophy.

Why, in Southern Italy during the 3rd century CE was Attis chosen for a mundus?

Finally, why Attis? As I stated before, to answer this question, the focus on when and where is crucial. The complicated and stratified late ensemble of doctrines and beliefs, which made Attis the perfect candidate to assure the initiate a different, better destiny in this world and/or in the netherworld, since he defeated - partially or in some late cases, totally, death - can find its origin, in fact, in Southern Italy. Here, indeed, where Pythagoreanism and Orphism boast a long-lasting tradition, Oriental influences were stronger than elsewhere in Italy (see the Metroac cult in Sicily, for instance) and, at least in Campania, there was the Etruscan presence, even though there were many centuries in between.

In this regard, I would like to recall the euhemeristic version of Diodorus Siculus (3. 58. 1 - 59. 8. 90). In this narrative, Attis is a human being, who dies but will be honored as a god after his death. In my opinion, being honored as a god is something even more than survival in death, because it implies the idea of immortality (achieved by a human). Moreover, despite the "humanized" setting in which the characters move, their principal features and their multiple connections with the sphere of nature, both animal and chthonian, do emerge. The mountainous setting, inhabited by beasts and shepherds, shows a fundamental aspect of the personality of Cybele who,

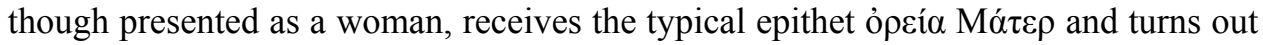
to be gifted with medical and cathartic powers in relation to the invention of the sacred musical instruments typical of the orgiastic cult. ${ }^{59}$

These typically Anatolian features of the Metroac cult are particularly evident in Sicily, the land of Diodorus. In Euripides, for instance, these specific "mountain" characteristics are, moreover, used to describe Demeter. ${ }^{60}$ Incidentally, the first men-

\footnotetext{
${ }^{57}$ According to this theory, Manes are between the Earth and the Moon, not in the underground; and Hades between the Zodiac and the Moon. From MARASTONI (n. 5) 246 ff., this is pivotal, since she thinks the link between the mundus and the underworld during the Empire is not important any more.

${ }_{59}^{58}$ MARASTONI (n. 5) 244.

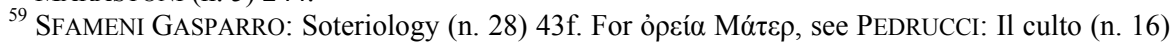
12-15, 22 (with previous bibliography).

${ }^{60}$ SFAMENI GASPARRO: Connotazioni (n. 23).
} 
tion of Cybele (as Kubaba) in the Western Mediterranean Sea is in Locri (Calabria, like the gold tablet above), not in Greece. The fact that Cybele/Kubaba is mentioned in two defixiones ${ }^{61}$ confirms her strongly chthonian aspect, which here, in this period (7th-6th century BC) has likely to be linked to her Anatolian origin. ${ }^{62}$

\section{CONCLUSIONS. THE $5 \mathrm{WS}$}

In order to come to some conclusions, it is useful to recall the results concerning the Ws:

What: a mundus, which is from the Late-Republican period a circular building with a ceiling vault, which is due to the influences of Pythagorean, Platonic and Orphic theories (plus Etruscan and more generally speaking Oriental doctrines). It represents the conjuncture point between earth and sky. The connection with underground gods and dead people is evident; it is likely that it had an underground chamber or a cave to come in contact more directly with them. It also had fertility functions (which is not unusual: at the same time, the Earth both houses dead people and gives new life).

Who: in our inscription, the mundus in sacred to Attis. The most famous mun$d u s$ is sacred to Ceres. Ceres/Demeter and Cybele are often juxtaposed and confused, but why do we have this sort of shift from Cybele to Attis?

When: 3rd century CE. Our sources on the Attis platonicus, his connection with the sun, and the explicit mention of life after death are a bit later, but the inscription comes from Campania, where, as I have tried to argue, certain doctrines could have developed earlier in comparison with Rome. Moreover, Campania had been an Etruscan land.

Where: In Magna Graecia certain doctrines had long-lasting traditions. It is therefore possible that some ideas might have found a more fertile terrain here than in Rome, where they caught on later. If we think of the Metroac cult, we can affirm that in Southern Italy (especially in Sicily) Anatolian features were preserved, and these were not present in the same way elsewhere, above all the worship of the goddess through the rock, by engraving it and penetrating it

Why: Even if our documentation does not confirm any kind of resurrection after death, as a stable and definitive recovery of life, there was, however, a survival "in death", in relation to the vegetal fertility, and there was a religiously defined presence

\footnotetext{
${ }^{61}$ For Cybele in the defixiones, see GORDON, R.: "Ut tu me vindices": Mater Magna and Attis in some new Latin Curse-Texts. In MASTROCINQUE - GiUfFrÉ SCIBONA (n. 46) 195-212; ŚMIEJOVÁ KeLLOVÁ (n. 30).

${ }^{62}$ PEDRUCCI: Il culto (n. 16) 37-40, 69-71. It is interesting to note that, at least in Caria during the Hellenistic period, there were two distinct divine figures: the Greek Mother of the Gods and the Phrygian Mother, each of them with its own priesthood. See MADDOLI, G.: Iasos: vendita del sacerdozio della Madre degli Dei. SCO 61.2 (2015) 101-118; NAFISSI, M.: Una dedica a Basileia da Iasos e il duplice culto della Madre degli Dei e della Madre Frigia. SCO 61.2 (2015) 119-136. This double aspect of Cybele is evident also in the Roman world, see PEDRUCCI, G.: Cibele e Attis a Roma: un culto orientale fra patriottica accettazione e sospettoso rifiuto. In BAGLIONI, I. (ed.): Saeculum Aureum. Tradizione e innovazione nella religione romana di epoca augustea. Rome 2016, 217-226.
} 
in the cult, characterized in its earliest forms by funeral lamentations (established by the goddess herself). These are the basis for the development of Attis as a single character, which would become a symbol of defeat over death and rebirth to a new life under the late Empire. In this process, Neoplatonic and Gnostic doctrines, together with Neopythagorean and Orphism theories, played a pivotal role; as well as the contrastive relationship with Christianity. ${ }^{63}$

Based on the collected data, the main conclusion is that the devotee/initiate of Cybele and Attis experienced, through the mundus, which had an underground part that can be seen as a womb, his temporary, not complete death and re-birth to a new life, as Attis himself did.

Giulia Pedrucci

Max Weber Centre for Advanced Cultural and Social Studies

University of Erfurt

Germany

${ }^{63}$ A very interesting detail is the connection, even though only secondary, between the mundus and the female sphere, since we are dealing with female goddesses and, above all, with eunuchs (Attis himself and his priesthood, as we all know). The noun $m u n \Theta$ in Etruscan language can refer, among other things, to an unknown female deity. Cf. n. 22. 
